E-Journal of Tourism Vol.8. No.1. (2021): 125-132

\title{
Creative Tourism in The Era of New Normality in The Advancement of Culture
}

\author{
Muhamad Muhamad*, Dina Ruslanjari, Azmy Hanif \\ Postgraduate School, Universitas Gadjah Mada Yogyakarta, Indonesia \\ *Corresponding Author: drmuhammad@ugm.ac.id
}

DOI: https://doi.org/10.24922/eot.v8i1.71453

Article Info
Submitted
January $18^{\text {th }} 2021$
Accepted
March $18^{\text {th }} 2021$
Published
March $31^{\text {th }} 2021$

Article Info

\begin{abstract}
Within the development of tourism in the era of new normality, especially for cultural tourism activities which do not only place tourists merely as spectators or connoisseurs, creative tourism is the main destination for alternative tourism, which is expected to maximize the potential for creative tourism for cultural advancement. The main objective of this study is to determine the position based on creative tourism to actualize the cultural advancement in the Yogyakarta Special Region and the Borobudur Temple Area. This study uses a qualitative research method with a case study approach with locations in the Yogyakarta Special Region and the Borobudur Temple area, Magelang Regency. Data collection techniques are carried out by observation and literature study, with a qualitative data analysis model based on theories of tourism development. The results of the research study show that the current stage of the development of creative tourism in the era of new normality in the Province of Yogyakarta Special Region and the Borobudur Temple Area, Magelang Regency is in between the consolidation of involvement between the industrial world and the stakeholders and the development of innovative products for cultural advancement.
\end{abstract}

Keywords: creative tourism, new normality, cultural advancement

\section{INTRODUCTION}

Nowadays, tourists have changed their tourism journey from buying products into buying experiences. Furthermore, there has been a change from mass tourism into responsible tourism. This tourism model has developed from the mass tourism model that only goes to a destination to take pictures and pay the destination a visit. In the next development, more tourists have been traveling to a destination to learn more about the local community, for example they are now visiting art galleries and festivals, tourist villages, museums, historical buildings and many other activities that will give them more experiences while traveling.

Development of the creative economy nowadays still faces many problems, challenges, and obstacles. The Ministry of Tourism and Creative Economy of Indonesia came up with Rencana Induk Ekonomi Kreatif: New Indonesian Powers through 2025 that has identified seven main issues that will be new challenges for the development of creative economy, which are creative human resources, materials, industrial com- 
petitiveness, finance, market, infrastructure and technology, institutional and business climate. In this global economy challenge, the government has been trying to support the development of the creative industry to become the strategic sector that will play a bigger role into the national economy especially to contribute more for the GDP (gross domestic product), job creations and exports. Many new policies for this development have been made, and some of them have been prioritized for the development of the creative economy as written in RPJM Nasional 2015-2019, which also established the Creative Economy Agency that will especially see through the development for the creative economy.

According to Prince (2011); Richards (2011); Marques (2012); Richards and Marques (2012); Lee and Lee (2015) some experts, there have been many requests related to tourism products, including creativity based tourism, or better known as creative tourism. The term creative tourism (creative based tourism) has gained a place in the answer in an economy filled with creative elements from destinations that have led to innovations in its development. According to the creative friendly by tourism network states:

"The Creative Tourism is considered a new generation of tourism that involves the tourists themselves and the locals in the creation of the tourist product (co-creation)."

With the terminology above, the experts consider creative tourism to be a new generation of tourism which involves the tourists themselves and local residents in the manufacture of tourism products (cocreation).

The growth and development of the creative economy at present, especially in tourist destinations such as Yogyakarta, means that tourism can not be separated from creative economy activities. As an example, the tourist activities in Yogyakar-

http://ojs.unud.ac.id/index.php/eot ta, especially at shopping centers like the culinary industry; gudeg, bakpia, geplak and others are scattered in the center of traditional foods. In addition, shopping tourism centers, such as Beringharjo Market and Malioboro, are the centers of creative industries that have become shopping destinations. This shopping tourism destination is a place for buying many handicraft or craft products. Looking at those examples, it is determined that the role of the creative economy is the most important part of tourism and can not be separated from tourism destinations and tourist activities.

According to Swesty (2019) the structure of the relationship between the creative economy is very much related for self-development as in the following explanation.

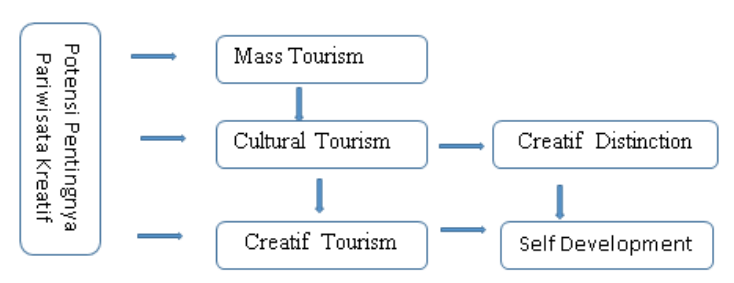

Figure 1. Self Development Requirement Stages. Source: Richards and Wilson (2007) (modified).

The requirements for basic human needs are: needing, wanting, having and behaving in which if those are juxtaposed into tourism types (mass tourism, cultural tourism and creative tourism), will result into another type of needs. According to Richards and Wilson (2007) the fulfillment of the basic needs are mass tourism to meet basic needs, creating distinctions is the purpose for cultural tourism, and then self development is the purpose for creative tourism. The emergence of creative tourism has been influenced by the changing of tourism motivation that will raise creative activities with active participants as an activity that will improve one's skills.

Many countries like New Zealand, e-ISSN 2407-392X. p-ISSN 2541-0857 
America, Austria, Spain, Canada, Taiwan and even Thailand have provided creative tourism activities as one of their tourism attractions. In Indonesia, creative tourism has not developed optimally even though it could be found easily in a lot of destinations, one of them are in Yogyakarta and Borobudur temple area. These two locations are very dominant in tourism development also as an effort to meet the supply of the creative industry as a trading commodity. But, even with creative tourism activities, Yogyakarta's reputation as a cultural city and Borobudur temple as a nation-wide heritage, these areas are still unable to develop properly. In the end, creative tourism has not been able to be a tourism that can afford creative industry products.

Talking about the creative industry in Yogyakarta and the Borobudur area which has unique industrial centers and is spread across four districts andcity and Bantul Regency is a district that has the most crafts compared to other districts which can be seen in the figure below which includes Yogyakarta City, Sleman Regency, Bantul Regency, Kulonprogo Regency and Gunungkidul Regency.

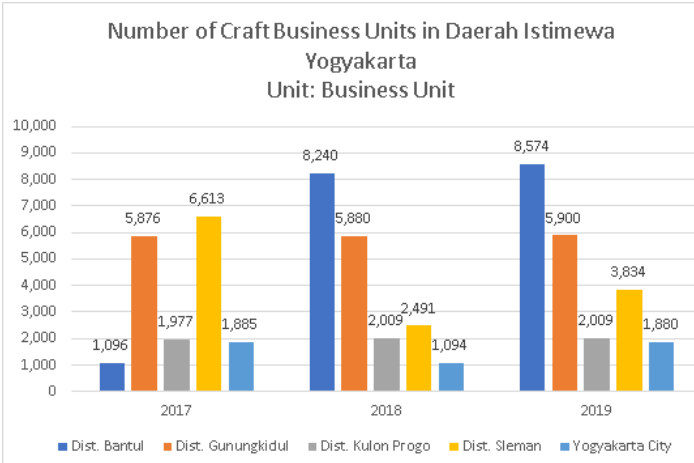

Figure 2. Number of Handicraft Business Units in Yogyakarta in 2017-2019. Source: BAPPEDA Yogyakarta (2020)

According to the description above, several research questions that will be explored in this study are: How is the creative tourism development in Yogyakarta during the pandemic? And what are the factors (internal and external) that influence the creative tourism development in Yogyakarta and Borobudur area?

\section{METHODS}

This research will use a case approach method (case study research). The research approach with the case study method is carried out intensively, in detail, and in depth on an individual, institution or certain symptoms with symptoms or narrow areas (Arikunto in Gunawan, 2016). This research is intended to formulate a form of creative tourism development in Yogyakarta and the Borobudur area. Types and sources of data and data collection methods are grouped into two types, namely primary data and secondary data as follows:

Table 3. Research Data

\begin{tabular}{ll}
\hline $\begin{array}{l}\text { Types of } \\
\text { Data }\end{array}$ & $\begin{array}{l}\text { Data Approach and Meth- } \\
\text { ods }\end{array}$ \\
\hline Primary & $\begin{array}{l}\text { Direct observation in art } \\
\text { centrals in Yogyakarta }\end{array}$ \\
Secondary & $\begin{array}{l}\text { Literature reviews on } \\
\text { journals, government } \\
\text { documents, geographic, } \\
\text { demographic, social and } \\
\text { economy data, govern- } \\
\text { ment agency reports. } \\
\text { Observation through Dinas } \\
\text { Koperasi, UKM, Perindus- } \\
\text { trian for more information } \\
\text { on UMKM and creative } \\
\text { tourism products. }\end{array}$ \\
\hline
\end{tabular}

Source: Authors (2018)

The technique for data collecting was done with interview and observation to obtain primary data. The interview was conducted in a semi-structured interview, using a list of questions that have been prepared and planned in advance. In this interview model, informants were asked for 
their opinions or ideas, because the purpose of this interview was to find problems more openly.

The data collection technique is carried out by sampling technique throughsnowball samplingby targeting who is the target, among others: tourists, craftsmen, heads of UPT, cooperatives, the Office of Cooperatives, UKM and Industry, Department of Tourism, and BPS, secondary data is obtained through literature study, literature, data in the form of sources of research results and publications through journals, books, research reports related to creative industries, creative tourism or destination development models.

\section{RESULTS AND DISCUSSION}

Internal factors that affect tourism development are attractions or tourist attractions in the process of making pottery and batik in 2019 and making visits. At that time, tourists were not interested in visiting. Next, many tourists are interested in buying products and other creative industry goods. During its development, many tourists are interested in witnessing the making of written batik, pottery and other industries.

The process of making hand-written batik and pottery by tourists, involves active participation of tourists, there is interaction between local people and tourists because they act as guides. There is a cultural exchange both in terms of language and experience when interactions occur. In the end, tourists will gain new knowledge and experiences from the results of creative tourism as a result of production tours of making pottery. This context can provide the most important feedback in efforts to promote local culture.

\section{External Factors Affecting the Devel- opment of Tourism in Kasongan Tour- ism Village.}

At present the role and influence of externalities is currently very supportive for various things in the development of the creative economy, several factors that influence and influence the development of tourism. 1) accessibility; 2) marketing

Table 4, Research aspects and required data.

\begin{tabular}{|c|c|c|c|}
\hline Research Aspects & Required & Methods of & Data Source \\
\hline $\begin{array}{l}\text { Destination Pro- } \\
\text { files in Yogyakarta } \\
\text { Special Region } \\
\text { Province }\end{array}$ & $\begin{array}{l}\text { Socio-economic data, de- } \\
\text { mographic data, history of } \\
\text { regional regulations and } \\
\text { governor regulations. }\end{array}$ & $\begin{array}{l}\text { Monitoring, } \\
\text { observation, in- } \\
\text { terview, litera- } \\
\text { ture review. }\end{array}$ & Bappeda. \\
\hline $\begin{array}{l}\text { Management } \\
\text { System for craft } \\
\text { center activity sys- } \\
\text { tems in destinations }\end{array}$ & $\begin{array}{l}\text { Stakeholders vision and mis- } \\
\text { sion, institutional manage- } \\
\text { ment, promotion, marketing, } \\
\text { tour packages, number of } \\
\text { visits, tourism village in- } \\
\text { come, partnership }\end{array}$ & $\begin{array}{l}\text { Observations, } \\
\text { Interviews, } \\
\text { Literature Re- } \\
\text { views }\end{array}$ & $\begin{array}{l}\text { Dinas Pari- } \\
\text { wisata, UPT } \\
\text { Koperasi, } \\
\text { District indus- } \\
\text { trial offices, } \\
\text { Dekranasda }\end{array}$ \\
\hline $\begin{array}{l}\text { Tourism Tourism } \\
\text { System (Attrac- } \\
\text { tions, Amenities, } \\
\text { Access, Ancillary) }\end{array}$ & $\begin{array}{l}\text { Institutions, Facilities, } \\
\text { Infrastructure, Institutions, } \\
\text { Transportation, Natural, } \\
\text { Cultural and Artificial } \\
\text { Attractions,Accommodations }\end{array}$ & $\begin{array}{l}\text { Observation, } \\
\text { Interviews, } \\
\text { Literature Re- } \\
\text { views }\end{array}$ & BPS. \\
\hline
\end{tabular}

Source: Analysis, 2016 
strategy; 3) networking (government, academics, and business / buyers); and 4) tourism development trends. The explanation of the external factors is as follows.

\section{Accessibility}

Indonesia has the potential for a world-class tourism industry by utilizing the wealth of tourism in a sustainable manner. Indonesia is one of the habitats with the largest biodiversity in the world. Indonesia also has a variety of tourism which is an attraction for tourists. The World Economic Forum (WEF) Travel and Tourism Competitiveness Report 2017 ranked Indonesia 14 (out of 136 countries) for its rich natural resources and 23rd for cultural resources and business travel.

The accessibility system aims to improve the quality of the road network, provide public transportation and nonmotorized means at the program location, and improve access to basic services and infrastructure that are important for tourists' satisfaction in enjoying the tour experience. This aims to improve the infrastructure needed for the preservation of natural and cultural wealth. The results of observations whether or not to improve the quality of infrastructure include components consisting of: There are external factors con- straints in the development of the creative industry, including: (i) poor access, quality of services and infrastructure for the community, visitors and entrepreneurs; (ii) limited skills of the workforce and tourism services from the private sector. If these obstacles can be overcome in an integrated manner, the creative industries in Yogyakarta and the Borobudur area will be able to develop an international tourism industry.

\section{Marketing Promotion Strategy}

External factors besides the accessibility that have been built, marketing strategies also affect tourism development. Along with development, the creative industry has received a lot of guidance from various kinds of agencies, both government and private parties. These agencies then help provide a display space, or gallery or art shop, many visitors or buyers who come. Marketing aspects do than to open the gallery, they are also reaching marketing medium in the form on line. This digital media is a way of informing and obtaining information in a fast and cheap way. Activities in order to support local companies to take advantage of economic opportunities in the tourism sector that increasingly rely on digital technology, including;

Table 5. Types of craftsmen in forming creativity in Yogyakarta and Borobudur area.

\begin{tabular}{ll}
\hline Type of Worker & Information \\
\hline $\begin{array}{l}\text { Artisans as creative individu- } \\
\text { als of Product creative }\end{array}$ & $\begin{array}{l}\text { craftsmen who only produce handicrafts are indig- } \\
\text { enous people who have been engaged in the business } \\
\text { of making the handicraft industry from generation to } \\
\text { generation (over generations) } \\
\text { producing creative industries by employing several } \\
\text { craftsmen and having their own gallery or show- } \\
\text { Crafters as: creative individu- } \\
\text { als who create creative products } \\
\text { and creative processes. }\end{array}$ \\
$\begin{array}{ll}\text { Crafters as creative individuals and forming environmental patterns in shap- } \\
\text { ing creativity. }\end{array}$ & $\begin{array}{l}\text { Crafters who employ and have the competence and } \\
\text { who create creative environ- }\end{array}$ \\
ability as independent craftsmen and have their own \\
ments and products and creative \\
processes.
\end{tabular}

Source: Analysis, 2020

http://ojs.unud.ac.id/index.php/eot 
Table 6. External Analysis in Efforts to Improve Accessibility Quality

\begin{tabular}{ll}
\hline Component & Accessibility Quality Improvement \\
\hline $\begin{array}{l}\text { Road transportation } \\
\text { services to improve } \\
\text { the quality and } \\
\text { condition of roads } \\
\text { related to tourism, }\end{array}$ & $\begin{array}{l}\text { Improve the quality and condition of roads related to tour- } \\
\text { ism, bridges, construction, widening, repair, reconstruction, } \\
\text { rehabilitation and maintenance, to meet national standards and } \\
\text { targets for steady road conditions by developing land transpor- } \\
\text { tation infrastructure to improve the quality and maintenance of } \\
\text { roads and bridges in accordance with standards national target } \\
\text { with stable maintenance conditions. }\end{array}$ \\
$\begin{array}{ll}\text { Infrastructure ser- } \\
\text { vices and tourism } \\
\text { services. }\end{array}$ & $\begin{array}{l}\text { non-motorized vehicles, construction of parks and green open } \\
\text { transport facilitios such as bus stops and terminals, docks, } \\
\text { ports where ships dock and ferry terminals, as well as taxi and } \\
\text { truck stops; }\end{array}$ \\
$\begin{array}{l}\text { Basic infrastructure } \\
\text { services related to } \\
\text { tourism }\end{array}$ & $\begin{array}{l}\text { such as drinking water supply, waste management, wastewater } \\
\text { management and sanitation in the core tourism area. }\end{array}$ \\
\hline Sol
\end{tabular}

Source: Analysis of various literature, 2020

Table 7. Necessary / Unnecessary Activities in basic infrastructure services

\begin{tabular}{|c|c|}
\hline Basic Infrastructure Activities & $\begin{array}{l}\text { Necessary / } \\
\text { Unnecessary }\end{array}$ \\
\hline \multicolumn{2}{|l|}{ THE ROAD SECTOR } \\
\hline Routine road maintenance; preventive maintenance of roads & Not \\
\hline Periodic maintenance / rehabilitation of roads & Not \\
\hline Road reconstruction / improvement & Not \\
\hline Road widening (adding lanes) & Yes \\
\hline Road construction * & Yes \\
\hline Routine maintenance, periodic maintenance, bridge rehabilitation & Not \\
\hline Bridge construction * & Yes \\
\hline $\begin{array}{l}\text { Planning, controlling and monitoring services for preservation and capacity } \\
\text { building of national roads }\end{array}$ & Not \\
\hline Tourism Infrastructure and Services & \\
\hline $\begin{array}{l}\text { new infrastructure for pedestrians, bicycles and non-motorized transportation, } \\
\text { such as sidewalks, trails, bicycle lanes, road crossings, pedestrian bridges. } \\
\text { Efforts to improve infrastructure for pedestrians, bicycles, and non-motorized }\end{array}$ & Yes \\
\hline $\begin{array}{l}\text { transportation, such as sidewalks, footpaths, bicycle lanes, road crossings, pe- } \\
\text { destrian bridges, and others }\end{array}$ & Not \\
\hline $\begin{array}{l}\text { City parks and garden improvement activities and green open spaces to beau- } \\
\text { tify the city }\end{array}$ & Not \\
\hline $\begin{array}{l}\text { City parks and garden development projects and green open spaces to beautify } \\
\text { the city }\end{array}$ & Yes \\
\hline & \\
\hline
\end{tabular}




\section{Networking (government, aca- demia, business / buyers)}

The third external factor that affects the development of tourism in Yogyakarta and the Borobudur area is the role of institutions (government, private sector and universities), and art traders from abroad (buyers). The first factor based on the analysis is the influence of several creators and observers of culture. Another factor is the existence and role of government, private and university institutions. The identification of the roles of these various institutions can be seen in the following Table 9 .

Another external factor that influences the development of the creative industry in the Yogyakarta region at this time or the new norm is the existence of art traders from abroad. Originally, these foreign art traders were tourists who came to visit Kasongan. They buy creative industries which are then attractive to their colleagues, and repeat purchases occur until they see prospects and business opportunities. They started to buy more and even used container trucks, along with a graph of the development of elements of export and import of the creative industry

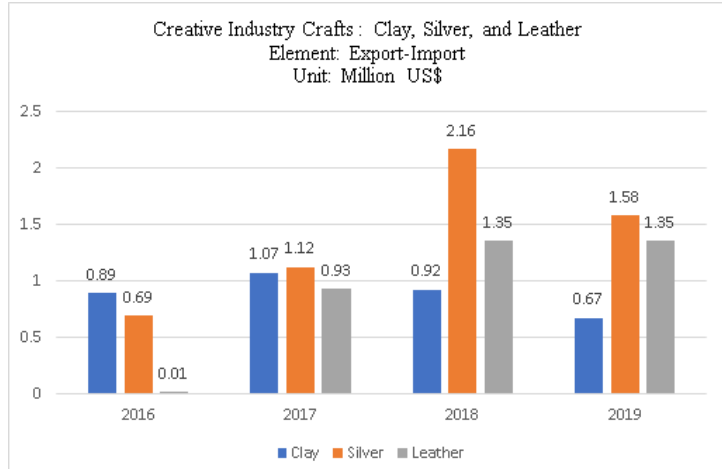

Figure 3. Creative Industry Crafts : Clay, Silver, and Leather. Source: BAPPEDA Yogyakarta (2020)

The presence of art traders (exporters) from abroad has influenced the creativity of craftsmen to produce products that suit the tastes of foreign markets. Ceramic

http://ojs.unud.ac.id/index.php/eot crafts that function as table chairs in cylindrical, rectangular, hexagonal, and octagonal shapes decorated with primitive-style scratching techniques and plant motifs are produced for Australia, Korea, Japan and Canada. The jars with the motifs of the moon, star and smiling sun are in great demand by the European, Australian and $\mathrm{Ca}-$ nadian markets as part of sales preparations for Christmas and summer holidays.In the 2000s, western society liked statues with traditional-spiritual values.

Several factors in tourism development trends also affect tourism development, some interviews revealed that there is a shift in traditional cultural trends starting with visits made to local communities, cultural sites and historic cities until this trend shifts to tourist participation in creative activities or events.

\section{CONCLUSIONS}

There are internal factors in the development of creative tourism in the new era that can shape creativity to attract creative tourism, namely; creative individual, creative environment, creative product and creative process. There is a process of cultural exchange both in terms of language and experience during interactions between tourists and creative industry creators in gaining new knowledge and experiences from the results of creative tourism, so as to provide the most important feedback in efforts to promote local culture.There are obstacles to these external factors in the development of the creative industry, including: poor access, quality of services and infrastructure for the community, visitors and entrepreneurs, limited skills of labor and tourism services from the private sector.

The stage of the development of creative tourism in the new normal era in Yogyakarta and the Borobudur Temple Area, Magelang Regency is at the stage of consolidation of involvement between the 
industrial world and stakeholders and the development of innovative products for cultural advancement.

\section{AKNOWLEDGEMENT}

Ministry of Research and Technology/National Research and Innovation Agency (RISTEK-BRIN). Master Program in Tourism Studies, Postgraduate School of Universitas Gadjah Mada, Yogyakarta. Universitas Gadjah Mada Directorate of Community Service, Yogyakarta.

\section{REFERENCES}

BAPPEDA Yogyakarta (2020) Number of Handicraft Business Units in Yogyakarta in 2017-2019. Available at: http://bappeda.jogjaprov.go.id/dataku/ pencarian_data/index?page $=1 \&$ perpage $=10$.

Gunawan, I. (2016) Metode Penelitian Kualitatif: Teori dan Praktik. Jakarta: Bumi Aksara.
Lee, J. and Lee, H. (2015) 'Deriving strategic priority of policies for creative tourism industry in korea using AHP', Procedia Computer Science, 55, pp. 479-484.

Marques, L. (2012) 'Boosting potential creative tourism resources: The case of Siby (Mali)'.

Prince, S. (2011) 'Establishing the connections between the goals of sustainable development and creative tourism'.

Richards, G. (2011) 'Creativity and Tourism The State of the Art', Annals of Tourism Research, 38(4), pp. 12251253.

Richards, G. and Marques, L. (2012) 'Exploring creative tourism: Editors introduction'.

Richards, G. and Wilson, J. (2007) Tourism, creativity and development. Routledge. 